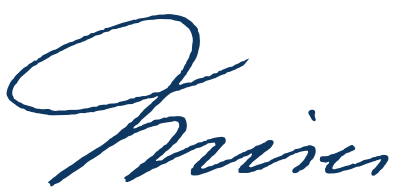

\title{
Note On An Error in Hazlitt's Economics in One Lesson
}

Walter Block ${ }^{\mathrm{I}}$ (D) 0000-0003-2215-4791

Loyola University, Nova Orleans, Luisiana, United States

\begin{abstract}
Economics in One Lesson is the best introduction to economics ever written. It has enticed, educated, and inspired multitudes of people to embrace the teachings of the dismal science. To the extent that if there is any understanding of economics by the general public, it is due more to this book than to any other. Yet, I have uncovered one error in it, which I attempt to rectify, offering a very slightly improvement to a priceless book on economics.
\end{abstract}

Keywords: Elasticity, Parity Prices, Costs, Profit.

\footnotetext{
${ }^{\text {I }}$ Walter Block is the Harold E. Wirth Eminent Scholar Endowed Chair in Economics at Loyola University, senior fellow of the Mises Institute, and regular columnist for LewRockwell.com. Email: wblock@loyno.edu
} 


\section{Nota sobre un error en la obra La economía en una lección}

Resumen: La economía en una lección es la mejor introducción a la economía que alguna vez se ha redactado. Ha atraído, educado e inspirado a multitudes de personas a abrazar las enseñanzas de la ciencia sombría. En la medida en que haya una comprensión de la economía por parte del público en general, esto se debe más a este libro que a cualquier otro. Sin embargo, he descubierto un error en él, cuya rectificación es mi intento de mejorar muy levemente un libro invaluable sobre economía.

Palabras clave: Elasticidad, precios de paridad, costos, ganancias.

\section{Nota sobre um erro na obra Economia em uma única lição}

Resumo: Economia em uma única lição é a melhor introdução à economia que já foi escrita. Atraiu, educou e inspirou milhares de pessoas a adotar os ensinamentos da ciência sombria. Na medida em que existe uma compreensão da economia por parte do público em geral, isso se deve mais a esse livro do que a qualquer outro. No entanto, descobri um erro nele, cuja retificação é minha tentativa de melhorar, levemente, um livro inestimável sobre economia

Palavras-chave: Elasticidade, paridade de preços, custos, lucros. 


\section{Introduction $^{1}$}

I owe my career in economics to Hazlitt (1946). ${ }^{2}$ I use this book in my introduction to microeconomics classes, and I am very grateful to its author for writing it. Economics in One Lesson is, in my opinion, the very best introduction to economics, bar none, ever written.

Why, then, besmirch this magnificent publication with criticism? There are several justifications for such an unseemly initiative. First, "you can't have too much of the truth." Truth is its own reward. Truth is the byword of our profession, and, indeed, of every profession worthy of its name. If we do not attempt to wield the "terrible swift sword" of truth wherever it leads us, without fear or favor, we are not worthy of the honorific, "economists." Second, from a pragmatic point of view, better that $\mathrm{I}$, a strong supporter of this book ${ }^{3}$ call into question one erroneous point made by Hazlitt, in order to very slightly improve the book, than to have a critic of this author's philosophy do so, in an attempt to discredit it. Thus, a benefit of the present criticism is that it might obviate one made with very different motives than those of its author.

First, the background (1946, p. 91):

The argument for parity prices ran roughly like this. Agriculture is the most basic and important of all industries. It must be preserved at all costs. Moreover, the prosperity of everybody else depends upon the prosperity of the farmer. If he does not have the purchasing power to buy the products of industry, industry languishes. This was the cause of the 1929 collapse, or at least of our failure to recover from it. For the prices of farm products dropped violently, while the prices of industrial products dropped very little. The result was that the farmer could not buy industrial products; the city workers were laid off and could not buy farm products, and the depression spread in ever-widening vicious circles. There was only one cure, and it was simple. Bring back the prices of the farmer's products to a parity with the prices of the things the farmer buys. This parity existed in the period from 1909 to 1914, when farmers were prosperous. That price relationship must be restored and preserved perpetually.

What, then, is the problematic passage? It occurs as a part of (HAZLITT, 2008, p. 95) rejection of "parity prices": "... when the farmer reduces the production of wheat to get parity, he may indeed get a higher price for each bushel, but he produces and sells fewer bushels. The result is that his income does not go up in proportion to his prices".

When price rises and quantity falls, what happens to total revenue? It all depends upon the elasticity of the demand curve between those two points; e.g., the lower the price and the higher the quantity with which we begin, the higher price and lower quantity at which point we end. If the demand curve is inelastic, the farmers' total revenue rises; if unitary,

\footnotetext{
${ }^{1}$ The author thanks a referee of MISES Journal for helpful suggestions, which greatly improved the present paper. The usual caveats of course apply.

${ }^{2}$ All references to this author, unless otherwise specified, will be to this particular publication.

${ }^{3}$ A vast understatement.
} 
then it remains the same; and if elastic, then it falls, as we move up and to the left along the demand curve ${ }^{4}$.

Suppose the former. We posit, then, that the demand curve is inelastic ${ }^{5}$ at its relevant section. That means the revenue accruing to the farmers rises. Does that logically imply that "his income does not go up in proportion to his prices?" Not necessarily. Hazlitt does not take cognizance of the fact that, when quantity falls, so do costs. This is true, to be sure, not if he burns his crops. Then, costs do not fall; they even rise, since setting them on fire is not a costless activity. However, if he does not plant these crops in the first place, he saves on land rent, ${ }^{6}$ fertilizer, seeds, and power for his tractor etc. Thus, his costs decrease. Then, given the cost concatenations, it is possible that the farm income "go up in more than proportion to his prices", contrary to Hazlitt's statement

Let us consider some numerical examples. We will illustrate this point in three ways. First, with a demand curve that is elastic within the bounds we are considering; second, with one that is inelastic; and; third, with one of unitary elasticity.

\section{Elastic case}

Suppose price rises from 10 to 11 , an increase of $10 \%$, while quantity falls from 100 to 90. Total revenue falls from $\$ 1000$ to $\$ 990$, and the elasticity between these two points on the demand curve is $21 / 19$, or elastic. In order to have a rise of more than $10 \%$ in income, we must go not from $\$ 1000$ to $\$ 990$, but from $\$ 1000$ to $\$ 1100$ or more. This would require a cost saving from the decrease in production of anything more than $\$ 110$. Posit that the cost saving is $\$ 120$, when quantity decreases from 100 to 90 . Then, revenue will increase from $\$ 1000$ to $\$ 1110$, a rise of more than $10 \%$. For costs to decrease by $\$ 120$ when quantity decreases by 10 units (from 100 units to 90 units) the average cost per unit must decrease by \$10; i.e., \$12/unit. However, if the original price was $\$ 10$ per unit, the original cost must have been no more than $\$ 10 /$ unit, assuming a viable enterprise. So, even if the firm were operating at breakeven originally and it raised its price to $\$ 11 /$ unit, cost must have dropped from $\$ 10 /$ unit to $-\$ 2 /$ unit for this scenario to work.

Is this logically possible? Yes. Anything that does not constitute a logical contradiction is possible, and this scenario does not constitute a logical contradiction. Is it plausible? Certainly not, under the assumption of a "viable enterprise." But not all enterprises are viable. In the real world, which we presume is the one which Hazlitt addresses, there are always some firms making a profit, others breaking even, and others yet undergoing losses. Since we are

\footnotetext{
${ }^{4}$ I say all this arguendo, given Barnett and Block (2010).

${ }^{5}$ This assumption flies in the face of standard microeconomic theory. No firm would knowingly operate where demand is inelastic. Thus, if the firm is operating in the elastic range, an increase in price reduces revenue. "Knowingly" is the key word here. Of course "No firm would knowingly operate where demand is inelastic." But, in the real world, firms do this unknowingly. And a full analysis of the economic situation of the world requires that we do not ignore this sector of the economy.
}

${ }^{6}$ Or the opportunity costs thereof. 
now discussing agriculture, the latter is more likely than in other industries. ${ }^{7}$ It is beyond the scope of the present paper to speculate on any such statistics; all we can say for sure is that for some farmers, this numerical example is likely. Hazlitt warns against (1946, p. 15-16, [emphasis added by the author]) "... the persistent tendency of men to see only the immediate effects of a given policy, or its effects only on a special group, and to neglect to inquire what the long-run effects $^{8}$ of that policy will be not only on that special group, but on all groups. Farmers who are losing money are a "special group" that we choose not to ignore.

\section{Inelastic case ${ }^{9}$}

Suppose price rises from 10 to 20, an increase of $100 \%$, while quantity falls from 100 to 90. Total revenue increases from $\$ 1000$ to $\$ 1800$, and the elasticity between these two points on the demand curve is $3 / 19$, or inelastic. In order to have a rise of more than $100 \%$ in income, or a doubling, we must go not from $\$ 1000$ to $\$ 1800$, but from $\$ 1000$ to $\$ 2000$ or more. This would require a cost saving from the decrease in production of anything more than $\$ 200$. Posit that the cost saving is $\$ 300$, when quantity decreases from 100 to 90 . Then, revenue will more than double from $\$ 1000$ to $\$ 2100$, a rise of more than $100 \%$. In this case $M R=+800 /-10=-80$ (per unit). Profit maximization (in this case, loss minimization) would require $M C=-\$ 80 /$ unit. This implies a cost saving of $\$ 20 /$ unit when price starts at $\$ 10 /$ unit. Again, if we are analyzing the situation of profit earning farmers, or of those breaking even, this scenario must be rejected. However, as Shakespeare informs us: "There are more things in heaven and earth, Horatio,

\footnotetext{
${ }^{7}$ The number of farming firms and the labor force participation in farming has been undergoing a long term downward trend. See on this AP (1988); U.S Census Bureau (2014; 2019). According to one source: "In the 1800s, 90 percent of the population lived on farms; today it is around one percent." Source: https://www. google.com/search?client=firefox-b-1-d\&ei=w13UXdKeLImWsQX2-YaQBw\&q=+farm+population+historical\&o $\mathrm{q}=+$ farm+population+historical\&gs_l=psy-ab.3...4546.4546..6673...0.2..0.84.84.1..............gws-wiz.......0i71.S-0drBrvqA\&ved=0ahUKEwiSjO-dm_flAhUJS6wKHfa8AXIQ4dUDCAo\&uact=5. Acessed: Jul 12019.

${ }^{8}$ Elasticities tend to be higher the greater the length of run. That is, there is more a response in quantity to price changes, the more time firms are given to adjust. In the immediate run, quantity is all but fixed, since little or nothing can be changed with notice of only a few seconds, or even minutes. But as more and more time is allowed, businesses become more flexible. It is not for nothing that major league pitchers hurl the ball toward the batter at speeds of 80 miles per hour or more. They do not want to give the batter time to adjust. When they pitch warmup to their own teammates before the game, the ball comes in at 40 miles per hour or so, and can usually be hit out of the park.

${ }^{9}$ In the view of mainstream economics, in perfectly competitive markets, we can have equilibrium in the inelastic part of demand curve, although each firm sees it as perfectly inelastic. In contrast, a monopolist, or a cartel that successfully lobbies for restrictions, will not operate in inelastic part of demand curve, for both revenues increases and costs decreases - and the cartel would reduce the quantity/increase the price. Austrian economists take a very different view of this matter. For the praxeological school, the important distinction is not between number of sellers (one or a few, monopoly, oligopoly; many, perfect competition), but rather whether or not there is freedom of entry (laissez faire capitalism), or restrictions on entry (crony capitalism or economic fascism). For more on this see Anderson et. al (2001); Armentano (1972; 1982; 1989; 1999), Barnett, et. al. (2005; 2007), Block (1977; 1982; 1994), Block and Barnett (2009); Boudreaux and DiLorenzo (1992); Costea (2003), DiLorenzo (1996; 1999; 1985), DiLorenzo and High (1988), Henderson (2013), High (1984; 1985), Hull (2005), McChesney (1991) McGee (1958), Rothbard (2004), Shugart (1987), Smith (1983), Tucker (1998a; 1998b).
} 
than are dreamt of in your philosophy." In our philosophy, there are also tillers of the soil who undergo losses.

\section{Unitary elasticity ${ }^{10}$}

Suppose price rises from 10 to 11 , an increase of $10 \%$, while quantity falls from 11 to 10 . Total revenue remains at $\$ 110$, and the elasticity between these two points on the demand curve is 1 , or elastic. In order to have a rise of more than $10 \%$ in income, we must go not from $\$ 110$ to $\$ 120$, but from $\$ 110$ to $\$ 121$ or more. This would require a cost saving from the decrease in production of anything more than $\$ 11$. Posit that the cost saving is $\$ 12$, when quantity decreases from 11 to 10 . Then, revenue will rise from $\$ 110$ to $\$ 122$, an increase of more than $10 \%$. To be sure, a cost a saving of $\$ 12$ for a one unit decrease in sales with an original price of $\$ 10 /$ unit means operating at a loss, and then having negative marginal cost. As we have seen, however, there is nothing implausible, let alone impossible, about such situation.

This error is no big deal. It is almost, but not quite, comparable to a typographical error. One would imagine that were Hazlitt to read this note, he would quickly acquiesce in the notion that if the cost savings of producing were sufficient, then, yes, the farmers' income could indeed rise more than in proportion to the price increase.

Nor is this error based on fallacious considerations such as the Giffen Good ${ }^{11}$. Here, there is nothing as untoward. It is just a simple failure to note that with a lower quantity, it is entirely possible that the costs of production will fall, and by an amount large enough so as to render Hazlitt's conclusion untrue.

\section{References}

ANDERSON, William et al. The Microsoft Corporation in Collision with Antitrust Law. The Journal of Social, Political and Economic Studies, v. 26, n. 1, p. 287-302, 2001.

AP. 1988. Farm Population Lowest Since 1850's. Available at: https://www.nytimes.com/1988/07/20/us/farmpopulation-lowest-since-1850-s.html. Acessed: Jul 12019.

ARMENTANO, Dominick T. The Myths of Antitrust. New Rochelle: Arlington House, 1972.

ARMENTANO, Dominick T. Antitrust and Monopoly: Anatomy of a Policy Failure. New York: Wiley, 1982.

ARMENTANO, Dominick T. Antitrust Reform: Predatory Practices and the Competitive Process. Review of Austrian Economics, v. 3, p. 61-74, 1989. Available at: http://www.mises.org/journals/rae/pdf/rae3_1_4.pdf. Acessed: Jan 12020.

${ }^{10}$ It is said that production can only take place in the elastic section of the demand curve, since marginal revenue will be less than zero in the inelastic section. But this is not quite true. Yes, it is indeed usually the case; but when losses are being registered, this no longer holds. Our economy is one of profits and losses, and it ill behooves us to ignore the latter.

${ }^{11}$ See on this Barnett and Block (2010), Block (2012), Block and Barnett (2012), Block and Philbois (2018), Block and Wysocki (2018), Klein (n/d), Klein and Salerno (s/d), Murphy, Wutscher and Block (2010) and Wysocki and Block (2018). 
ARMENTANO, Dominick T. Antitrust: The Case for Repeal. Auburn: Mises Institute, 1999.

ARMSTRONG, Don. Competition vs. Monopoly. Vancouver: The Fraser Institute, 1982.

BARNETT, William II; BLACK, Walter E. Mises never used demand curves: was he wrong? Ignorant? No: The Antimathematicality of Demand Curves. Dialogue, v. 1, p. 23-31, 2010. Available at: http://www.uni-svishtov. bg/dialog/title.asp?lang=en\&title=101. Acessed: Jul 12019.

BARNETT, William; BLOCK, Walter E.; SALIBA, Michael. Perfect Competition: A Case of Market-Failure. Corporate Ownership \& Control, v. 2, n. 4, p. 70-75, 2005.

BARNETT, William II; BLOCK, Walter E.; SALIBA, Michael. Predatory pricing. Corporate Ownership \& Control, v. 4, n. 4, p. 401-406, 2007.

BLOCK, Walter E. Thymology, praxeology, demand curves, Giffen goods and diminishing marginal utility. Studia Humana, v. 1/2, p. 3-11, 2012. Available at: http://studiahumana.com/pliki/wydania/Thymology,\%20 praxeology,\%20demand\%20curves,\%20Giffen\%20goods\%20and\%20diminishing\%20marginal\%20utility. pdf; wageshttp://studiahumana.com/art,The-second-issue,Thymology-Praxeology-Demand-Curves-GiffenGoods-and-Diminishi.html. Acessed: Jul 12019.

BLOCK, Walter E.; BARNETT, William II. Giffen Goods, Backward Bending Supply Curves, Price Controls and Praxeology. Revista Procesos de Mercado, v. 9, n. 1, p. 353-373, 2012.

BLOCK, Walter E.; PHILBOIS, Gabriel. Giffen Goods and Backward Bending Supply Curves of Labor. Revista Estudios Libertarios, v. 1, p. 55-69, 2018. Available at: http://www.notaslibertarias.com/vol-1-2018/. Acessed: Jul 12019.

BLOCK, Walter E. Austrian Monopoly Theory - a Critique. The Journal of Libertarian Studies, v. 1, n. 4, p. 271-279, 1977.

BLOCK, Walter E. Amending the Combines Investigation Act. Vancouver: The Fraser Institute, 1982.

BLOCK, Walter E. Total Repeal of Anti-trust Legislation: A Critique of Bork, Brozen and Posner. Review of Austrian Economics, v. 8, n. 1, p. 35-70, 1984.

BLOCK, Walter; BARNETT, William. Monopsony Theory. American Review of Political Economy, v. 7, n. 1/2, p. 67-109, 2009. Available at: http://www.arpejournal.com/ARPEvolume7number1-2/Block-Barnett.pdf. Acessed: Jan 12020.

BLOCK, Walter E.; WYSICKI, Igor. A defense of Rothbard on the demand curve against Hudik's critique. Acta Economica et Turistica, p. 47-61, 2018. Available at: https://hrcak.srce.hr/index.php?show=clanak\&id_clanak_ jezik=296319. Acessed: Jan 12020.

BOUDREAUX, Donald J.; DILORENZO, Thomas J. The Protectionist Roots of Antitrust. Review of Austrian Economics, v. 6, n. 2, p. 81-96, 1992.

COSTEA, Diana. A Critique of Mises's Theory of Monopoly Prices. The Quarterly Journal of Austrian Economics, v. 6, n. 3, p. 47-62, 2003. Available at: http://www.mises.org/journals/qjae/pdf/qjae6_3_3.pdf. Acessed: Jan 12020.

DILORENZO, Thomas J. The origins of antitrust: an interest-group perspective. International Review of Law and Economics, v. 5, p. 73-99, 1985. Available at: http://mason.gmu.edu/ trustici/LAW108/The\%20Origins\%20 of\%20Antitrust-\%20An\%20Interest\%20Group\%20Perspective.pdf. Acessed: Jan 12020.

DILORENZO, Thomas J. The Myth of Natural Monopoly. Review of Austrian Economics, v. 9, n. 2, p. 43-58, 1996. Available at: http://www.mises.org/journals/rae/pdf/rae9_2_3.pdf. Acessed at: Jul 12019.

DILORENZO, Thomas J. The Truth About Sherman. Available at: https://mises.org/library/truth-about-sherman. Acessed: Nov 82019.

DILORENZO, Thomas J.; HIGH, Jack. Antitrust and Competition, Historically Considered. Economic Inquiry, v. 26, n. 1, p. 423-435, 1998. 
HAZLITT, Henry. Economics in One Lesson. Auburn: Mises Institute, 2008 [1946].

HENDERSON, David R. The Robber Barons: Neither Robbers nor Barons. Library of Economics and Liberty, 2013. Available at: http://www.econlib.org/cgi-bin/printarticle2.pl?file=Columns/y2013/Hendersonbarons.html. Acessed: Mar 242019.

HIGH, Jack. Bork's Paradox: Static vs Dynamic Efficiency in Antitrust Analysis. Contemporary Policy Issues, v. 3, p. 21-34, 1985.

HULL, Gary. The Abolition of Antitrust. New Brunswick: Transaction Publishers, 2005.

KLEIN, Peter G. A note on Giffen goods. Unpublished, n/d. Available at: http://web.missouri.edu/ kleinp/misc/ giffen.pdf. Acessed: 1 Jul 2019.

KLEIN, Peter G.; SALERNO, Joseph T. Giffen's Paradox and the Law of Demand. Unpublished, n/d. Available at: https://mises.org/library/giffen\%E2\%80\%99s-paradox-and-law-demand. Acessed: 1 Jan 2020.

MCCHESNEY, Fred. Antitrust and Regulation: Chicago's Contradictory Views. Cato Journal, v. 10, 1991.

MCGEE, John S. Predatory Price Cutting: The Standard Oil (New Jersey) Case. The Journal of Law and Economics, p. 137-169, 1958.

MURPHY, Robert P.; WUTSCHER, Robert; BLOCK, Walter E. Mathematics in Economics: An Austrian Methodological Critique. Philosophical Investigations, v. 33, n. 1, p. 44-66, 2010. Available at: http://onlinelibrary. wiley.com/doi/10.1111/j.1467-9205.2009.01397.x/full. Acessed: Jan 12020.

PHILBOIS, Gabriel; BLOCK, Walter E. The Z Curve: Supply and Demand for Giffen Goods. MISES: Interdisciplinary Journal of Philosophy, Law and Economics, v. 6, n. 3, 2018. Available at: https://misesjournal.org.br/misesjournal/ article/view/311. Acessed: Jan 12020.

ROTHBARD, Murray N. Man, Economy and State. Auburn: Ludwig von Mises Institute, 2004 [1962].

SHUGART, William F. Don't Revise the Clayton Act, Scrap It!. Cato Journal, v. 6, 1987.

SMITH, Jr.; FRED, L. Why not Abolish Antitrust?, Regulation 1983. Available at: http://cei.org/op-eds-andarticles/why-not-abolish-antitrust. Acessed: Jan 232020.

TUCKER, Jeffrey. Controversy: Are Antitrust Laws Immoral?. Journal of Markets \& Morality, v. 1, n. 1, 1998 a. Available at: http://www.acton.org/publications/mandm/mandm_controversy_35.php. Acessed: Jul 12019.

TUCKER, Jeffrey. Controversy: Are Antitrust Laws Immoral? A Response to Kenneth G. Elzinga. Journal of Markets \& Morality, v. 1, n. 1, p. 90-94, 1998b. Available at: http://www.acton.org/publications/mandm/ mandm_controversy_37.php. Acessed: Jul 12019.

U.S. Census Bureau 2014. Available at: https://www.census.gov/prod/www/agriculture.html. Acessed: Jul 12019.

U.S. Census Bureau 2019. Available at: https://www.nass.usda.gov/AgCensus/. Acessed: Jan 12020.

WYSOCKI, Igor; BLOCK, Walter E. The Giffen good - a praxeological approach. Ekonomia Wrocław Economic Review, v. 24, n. 2, p. 9-22, 2018. Available at: http://repozytorium.uni.wroc.pl/dlibra/publication/100651/ edition/94179/content?ref=desc. Acessed: Jul 12019. 